\title{
Correction to: Uncertainty estimation of the determination of chemical sum parameters in water
}

\author{
Tony Venelinov ${ }^{1}$
}

Published online: 10 October 2017

(C) Springer-Verlag GmbH Germany 2017

\section{Correction to: Accred Qual Assur DOI 10.1007/s00769-017-1276-6}

Unfortunately, Eq. 3 was incorrectly presented in the original publication. The correct version of Eq. 3 is

$u_{\text {ip }}=\frac{s_{d}}{\sqrt{d}}=\sqrt{\frac{M S_{\text {betweengroup }}-M S_{\text {withingroup }}}{n_{\text {pergroup }}}}$, where $u_{\mathrm{ip}}$ is the uncertainty due to intermediate precision, $s_{\mathrm{d}}$ is the day-to-day variation, $d$ is the number of measurement days, $M S_{\text {betweengroup }}$ is mean of squares between the groups, $M S_{\text {withingroup }}$ is mean of squares within the groups, and $n_{\text {pergroup }}$ is the number of replicates.

The online version of the original article can be found under doi:10.1007/s00769-017-1276-6.

Tony Venelinov

tvenelinov_fhe@uacg.bg

1 Faculty of Hydraulic Engineering, Chair of Water, Sewerage,

Water and Wastewater Treatment, University of Architecture,

Civil Engineering and Geodesy, $1 \mathrm{Hr}$. Smirnenski blvd.,

1164 Sofia, Bulgaria 